\title{
THE FAUNA OF THE ARUNDEL FORMATION OF MARYLAND.
}

\section{By Charles W. Gilmore.}

Associate Curator, Division of Paleontology, United States National Museum.

\section{INTRODUCTION.}

The vertebrate fauna of the Arundel formation of Maryland has long been a subject of interest to all workers in American Mesozoic formations. The correlation of this fauna with the Morrison (Atlantosaurus, Como) beds fauna of the Rocky Mountain region by Prof. O. C. Marsh, and the later ${ }^{1}$ and more positive confirmation of that conclusion by Dr. R. S. Lull, has been quite generally accepted as the correct interpretation. The present communication gives the results of a more recent study of all known specimens from the Arundel formation, and the conclusions reached are quite at variance to those of my predecessors. The evidence appears to show-first, that the vertebrate fauna as a whole is not to be closely correlated with that of the Morrison formation of the West; second, that it contains forms having undoubted Upper Cretaceous affinities; third, that it consists of a combination of dinosaurian forms hitherto unknown in any fauna of this continent-that is, the intermingling of Sauropodous dinosaurs with those having Upper Cretaceous affinities.

While the discussion of several phases of this question are necessarily inconclusive, due to the paucity of the materials, yet the main contentions, I believe, can be fully maintained.

\section{SOURCE OF MATERIALS.}

Practically all of the vertebrate materials known from the Arundel formation of Maryland are now assembled in the United States National Museum. These comprise all of the specimens collected by the late J. B. Hatcher, in 1887 and 1888 for the United States Geological Survey; the Goucher College collection brought together by Prof. Arthur Bibbins during the years 1894, 1895, and 1896; and a few single specimens that have been acquired by the United States National Museum from various sources.

1 Maryland Geol. Survey, Lower Cretaceous, 1911, pp. 173-178. 
The Government materials which form the bulk of the collection, as said by Hatcher, ${ }^{2}$ were "found in a bed of iron ore near Bladensburg [Muirkirk], Maryland. The exact locality of the Marsh material was certain iron ore mines on the farm of Mr. William Coffin, and especially in that one locally known as "Swampoodle" and situated about $1 \frac{1}{2}$ miles northeast of Beltsville, on the Baltimore \& Ohio Railway, some 13 miles from Washington."

As to the occurrence of these fossils Hatcher says:

No two bones or fragments of all that material collected from the Potomac beds in Maryland were found in such relation to one another as to demonstrate that they belonged to the same individual. In any discussion as to the affinities of these various genera and species of small Sauropod dinosaurs, not only the immature nature of the remains upon which they have been based, but also the scattered and disarticulated state in which found, must be constantly borne in mind.

The above remarks as to the scattered state of the specimens apply equally well to those other remains in the collection, subsequently brought together by Professor Bibbins and others.

\section{THE ARUNDEL FAUNA.}

Our knowledge of the Arundel fauna had its beginning as early as 1859, when Dr. Christopher Johnston gave the gener ic name Astrodon ${ }^{3}$ without description to certain reptilian teeth obtained by a Mr. Tyson from a bed of iron ore near Bladensburg, Maryland.

In 1865 these teeth were fully described and figured as Astrodon johnstoni by Dr. Joseph Leidy, ${ }^{4}$ they being the first remains of a Sauropod dinosaur to be named and described from North America.

Twenty-three years later Prof. O. C. Marsh made the next contribution ${ }^{5}$ to our knowledge of this fauna, when he established two genera and five new species all pertaining to the dinosauria. These were Pleurocoelus nanus, P. altus, Priconodon crassus, Allosaurus medius, and Coelurus gracilis. The presence of turtle and crocodilian remains was mentioned, but it was 10 years later that Dr. O. P. Hay, described a turtle under the name of Glyptops caelatus. ${ }^{6}$

The next important paper dealing with this fauna was that by Prof. R.S. Lull ${ }^{7}$ in which he revised and described all of the materials available at that time. Two species of dinosaurs Creosaurus potens, Dryosaurus grandis and a crocodilian reptile Goniopholis affinis were described as new, and the presence of a fossil gar fish was mentioned for the first time.

Annals of the Carnegie Museum, vol. 2, 1903, pp. 11-13.

3 Amer. Journ. Dental Sci., vol. 9, 1859, p. 341.

4 Smiths, Contr. Knowl., vol. 14, art. 6, 1865, pp. 102-119, pl. 13, figs. 20-23; pl. 20, fig. 10.

- Amer. Journ. Sci., ser. 3, vol. 25, 1888, pp. 89-94.

- Fossil Turtles of North America, Carnegie Institution, Washington, 1908, pp. 52, 53, pl. 7, figs. 1, 2.

7 Rept. Geol. Survey of Maryland, Lower Cretaceous, 1911, pp. 173-211, pls. 11-20. 
The complete fauna as recognized by Lull in 1911, and the revised fauna as now determined by Gilmore are shown in the two parallel columns below:

Vertebrate Fauna of the Arundel Formation.

Theropoda.

Listed by Lull in 1911. Allosaurus medius Marsh. Creosaurus potens Lull. Coelurus gracilis Marsh.

Pleuroceolus nanus Marsh. Pleuroceolus altus Marsh. Astrodon johnstoni Leidy.

Priconodon crassus Marsh. Dryosaurus grandis Lull.

Goniopholis affinis Lull.

Glyptops caelatus Hay.

Ganoid fish.
Revised by Gilmore in 1921. Dryptosaurus? medius (Marsh). Dryptosaurus? potens (Lull). Coelurus? gracilis Marsh. Ornithomimus affinis Gilmore

SAUROPODA.

Astrodon nanus (Marsh). Astrodon altus (Marsh). Atrodon johnstoni Leidy.

ORTHOPODA.

Priconodon crassus Marsh.

\section{Crocodylia.}

Goniopholis? affinis Lull.

Testudinata.

Glyptops caelatus Hay.

Pisces.

Ganoid fish.

Undetermined fish.

The reasons for the above changes in the 1921 list are discussed below under their respective headings in the order as given above.

DISCUSSION OF THE MEMBERS OF THE ARUNDEL FAUNA.

\section{Order DINOSAURIA.}

\section{DRYPTOSAURUS? MEDIUS (Marsh).}

Plate 110, fig. 2.

This species was originally established by Marsh on a number of cotypes, ${ }^{8}$ all but one, the crown of a single large tooth (Cat. No. 4972 , U. S. N. M.), Lull subsequently removed to the genus Dryosaurus, as the cotypes of the new species $D$. grandis Lull, ${ }^{9}$ and more recently referred by $\mathrm{me}^{10}$ to the genus Ornithomimus. At this time Dryptosaurus? medius rests on a single tooth shown in plate 110 , figure 2. So far as the type material is concerned it will always

\footnotetext{
${ }^{8}$ Amer. Journ. Sci., vol. 35, 1888, p. 93.

9 Maryland Geol. Survey, Lower Cretaceous, 1911, pp. 183-186.

${ }^{10}$ Bull. 110, U. S. National Museum, 1920, pp. 119-121.
} 
remain a form of doubtful affinities. It is determinable as to suborder (the Theropoda), but in the present state of our knowledge concerning the carnivorous dinosauria it is not determinable generically, and should therefore be regarded as an indeterminate type.

The few scattered bones referred to this species by Lull can be assigned, with equal propriety, to Dryptosaurus? potens Lull, founded on a somewhat more adequate type. I have already, in the paper cited above, attempted to show that two caudal vertebrae, from the distal part of the tail formerly referred to this species, probably pertain to an Ornithomimid dinosaur, and some of the other bones may eventually find a similar fate in other directions.

It is quite probable that these scattered elements represent more than one kind of the large carnivorous dinosauria in this formation, but to definitely determine that fact more diagnostic materials must necessarily be found.

\section{DRYPTOSAURUS? POTENS (Lull).}

Plate 111, fig. 2.

This species was originally referred by Lull ${ }^{11}$ to the genus Creosaurus, a genus established by Marsh on materials from the Morrison formation of Wyoming. In a recent paper ${ }^{12}$ giving the results of a detailed study and comparison of the type with other Theropod specimens I arrived at the following conclusions:

1. That the genus Creosaurus should be abandoned to become a synonym of Antrodemus.

2. That the type specimen, consisting of a single vertebral centrum (see pl. 111, fig. 2), pertains to the caudal series and not to the presacral region as originally determined.

3. That a comparison of the type specimen with the homologous element in Antrodemus (compare figs. 1 and 2, pl. 111), shows such dissimilarities as to render its assignment to that genus out of the question.

4. That the closest resemblance of the type vertebral centrum appears to be with the caudals of Dryptosaurus aquitunguis Cope (compare fig. 2, pl. 111, with fig. 2, pl. 114), and it was therefore provisionally referred to that genus.

When viewed in profile the straightness of the ventral border with distinct keel at once distinguishes this bone from all known carnivorous dinosaurs of the Morrison formation. In Tyrannosaurus and Gorgosaurus from the western Upper Cretaceous the concavity of the lower border of the anterior caudal vertebrae is markedly straighter than in any of the Morrison Theropods, and in Dryptosaurus as figured by Cope (see pl. 114, fig. 2), from the Upper Cretaceous of 
New Jersey is found the nearest approach to the straight ventral border of the specimen under consideration.

Although fully recognizing the inadequate nature of the type material the resemblances pointed out above appear highly significant, and taken in conjunction with their similar geographical distribution leads me to believe its assignment to Dryptosaurus to be the logical disposition of this species at this time.

\section{COELURUS? GRACILIS Marsh.}

Plate 110, fig. 5 .

Coelurus gracilis Marsh was also established on a very poor specimen consisting of an ungual phalanx, the tip of which is missing, as shown in plate 110 , figure 5 .

The original description is as follows:

The smallest Dinosaur found in these deposits is a very diminutive carnivore, apparently belonging to the genus Coelurus. It was not more than one-half of the size of the western species and its proportions were extremely slender. The bones are very light and hollow, the metapodials being much elongated and their walls extremely thin. An ungual phalanx of the manus measures about $25 \mathrm{~mm}$. in length and $14 \mathrm{~mm}$. in vertical diameter at the base. This animal could not have been more than 5 or 6 feet in length.

One would infer from the above description that Marsh had other bones besides the ungual, but I find none in the collection which could by any stretch of the imagination be so referred.

Three teeth in the Goucher College collection were referred by Lull to this form, two of them having come from the same locality as the type. These, of course, have been arbitrarily associated. The comparison of these teeth with the tooth of Coelurus fragitis, figured by Marsh ${ }^{13}$ from the Morrison and which Lull has shown differ considerably in the almost total reduction of the crenulation of the anterior convex border, and their larger size, offers but little assistance in getting at the true affinities of these teeth. Furthermore, as I have shown ${ }^{14}$ the tooth of $C$. fragilis does not belong to the type materials, it having been received at the Yale Museum some time in advance of the type, so there is no evidence of their association.

That the (type) ungual pertains to the fore foot of a small carnivorous dinosaur there can be no question, but that it is referable to the genus Coelurus remains to be demonstrated. In the present state of our knowledge of the carnivorous dinosauria I doubt the possibility of determining the genus to which it belongs, at least with any certainty of the correctness of the identification.

A careful comparison of the type specimen has been made with all available carnivore unguals in the collections of the United States

${ }^{13}$ 16th Ann. Rep. U. S. Geol. Surv., pt. 1, 1896, pl. 7, fig. 1.

is Bull. 110, U. S. National Museum, 1920, p. 128. 
National Museum and the American Museum of Natural History, from the Morrison, Lance, and Belly River formations, and those which were found to resemble it most nearly were from the Belly River formation. No fewer than four unguals in the American Museum of Natural History collections, except for their larger size, were exact counterparts of the bone under consideration (compare figs. 4 and 5, pl. 110). None of these, however, have been identified. One of them is illustrated here together with the type to show their close resemblance. While the observations recorded above may be of little moment, it appears significant that two bones from widely separated geological horizons should show such startling close resemblances, especially. since the Arundel fauna contains other members that have unquestioned Upper Cretaceous affinities.

\section{ORNITHOMIMUS AFFINIS Gilmore.}

Plate 112, figs. 1 and 3; plate 113, figs. 1 and 3; plate 114, fig. 1 .

Ornithomimus affinis was founded ${ }^{15}$ on a number of cotypes, consisting of an astragalus, metatarsals, and other elements of the hind feet. In $1888^{16}$ those same bones were used by Prof. O. C. Marsh as the cotypes of the species Allosaurus medius, all of which excepting a tooth were subsequently referred by Lull ${ }^{17}$ to the Orthopoda and to the new species Dryosaurus grandis. In a recent paper ${ }^{18}$ I have shown that these cotypes do not pertain to the herbivorous dinosauria but to the carnivorous Theropoda, and in all probability to the genus Ornithomimus. The species name "grandis" having been previously used, it became necessary to assign a new name and the term $O$. affinis was selected to designate this species.

The recognition of an Ornithomimid dinosaur in the Arundel fauna was entirely unexpected for previously representatives of the family Ornithomimidae had only been known from the Judith River, Belly River, Edmonton, Denver, and Lance formations of the Rocky Mountain region, all Upper Cretaceous, while the Arundel on the highest authority, has been regarded of Lower Cretaceous age. Thus the range of this dinosaurian family is greatly extended both geologically and geographically.

Since these cotypes have been described in detail in a recent paper ${ }^{19}$ it appears unnecessary to do more here than to call attention to those features which demonstrate the Theropod nature of these bones, followed by a summary of the reasons for assigning them to the genus Ornithomimus.

15 Bull. 110, U. S. National Museum, 1920, pp. 137.

${ }^{16}$ Amer. Journ. Sci., vol. 35, 1888, p. 93.

${ }_{17}$ Lower Cretaceous, Geol. Survey of Maryland, 1911, pp. 183-186.

${ }_{18}$ Bull. 110, U. S. National Museum, 1920, pp. 137-142.

${ }^{19}$ Idem, pp. 137-142. 
In the parallel columns below the Theropod nature of the cotypes are clearly demonstrated by contrasting their important structural features with the homologous bones of the Orthopod hind foot.

Theropod characteristics of the cotypes of Ornithomimus affinis.

\section{Characteristics of the Orthopod pes.}

1. Astragalus with ascending process.

2. Astragalus narrow fore and aft as compared with transverse diameter.

3. Articular surface on distal end of metatarsal III, extending higher on front than on back of bone.

4. Unguals of hind feet compressed.

5. Lateral pits on distal ends of foot bones deep and their borders well defined.

6. Articular ends of foot bones, having well finished surfaces.

1. Ascending process always absent.

2. Astragalus wide fore and aft, as com pared with transverse diameter.

3. Extent of articular surface on front and back of distal end of metatarsal III, subequal.

4. Unguals of hind feet depressed.

5. Lateral pits on distal ends of foot bones shallow or wanting, their borders when present, illy defined.

6. Articular end of foot bones, usually lacking refinement of their surfaces.

The Ornithomimid character of these cotypes was established by a direct comparison with the foot bones of the fine skeleton of Ornithomimus (Struthiomimus) altus Lambe and other Ornithomimid materials in the American Museum of Natural History, New York. In every instance such close resemblances were found as to leave little doubt of their generic identity.

For the present purposes it is thought the similarities of these bones may be most clearly demonstrated by showing homologous bones of the Arundel and Belly River Ornithomimids side by side. In plates 112 and 113 are thus illustrated a number of these bones reproduced here from photographs. Their close similarities, in some instances, down to the minutest details appears to me to be sufficient to demonstrate their pertaining to animals of congeneric relationship.

\section{SAUROPODOUS DINOSAURS.}

Prof. R. S. Lull has given such a thorough and detailed discussion ${ }^{20}$ of the Sauropod Dinosaur remains from the Arundel formation that for the present purposes a detailed discussion of them appears unnecessary. After a thorough examination of the materials I fully concur in his conclusions. Lull recognized three species of Sauropodous dinosaurs from the Arundel Astrodon johnstoni, Pleurocoelus nanus, and $P$. altus. Hatcher contended ${ }^{21}$ that-

Since these remains were found in essentially and perhaps identically the same locality and horizon, and, in consideration of the very great similarity which they exhibit, there appears no good reason for considering them as pertaining to either different genera or species. Astrodon johnstoni Leidy, having priority, should, therefore, be retained, while Pleurocoelus nanus would become a synonym of that genus and species.

${ }^{20}$ Lower Cretaceous, Md. Geol. Survey, 1911, pp. 188-204.

${ }^{21}$ Annals Carnegie Museum, vol. 2, 1903, pp. 11-12. 


\section{Lull observes:}

I am inclined to agree with Hatcher in considering Astrodon and Pleurocoelus synonyms, but not in the synonym of the species, $P$. nanus with Astrodon johnstoni: * * * Pleurocoelus altus, on the other hand, is represented by but few bones, and could readily have been the possessor of teeth like those of Astrodon johnstoni. * * * It is therefore quite possible that Pleurocoelus altus should be considered as synonymous with Astrodon johnstoni, in which case the latter name would take precedence. It seems preferable, however, in view of the rarity of the remains, to let the matter rest in abeyance until further proof is obtained.

The materials clearly show the presence in the Arundel of a large and small species of the Sauropodous dinosauria, and while I fully concur in Lull's view of the continued use of all the named species, I think it preferable to assign all to the genus Astrodon, which clearly has priority.

\section{PRICONODON CRASSUS Marsh.}

Plate 110, fig. 3.

Priconodon crassus was founded by Marsh ${ }^{22}$ on a single tooth (Cat. 2135, U. S. N. M.) (see pl. 110, fig. 3), his original description being as follows:

The existence of another herbivorous dinosaur in the same horizon of the Potomac formation is indicated by a number of fragmentary remains, the most characteristic of which is the tooth figured below. This may be regarded as the type specimen. Although resembling somewhat the teeth of Diraconodon [Diracodon] from the Jurassic of the West, it is quite distinct. It has the narrow neck, swollen base, and flattened crown of that genus, but the serrated edges meet above at a sharp angle, instead of forming a wide curve at the apex. The surface shown in fig. 7 [pl. 110, fig. 3, left] is much worn by the opposing tooth. In figure 9 [pl. 110, fig. 3 , right] the pit formed by the succeeding tooth is seen near the top of the fang.

Lull, in his study ${ }^{23}$ of the Arundel vertebrates, consisting of the type and subsequently discovered materials, recognized five other teeth pertaining to Priconodon crassus, and a vertebral centrum was questionably referred by him to this species. The latter I regard as pertaining to the sacrum, and have tentatively assigned ${ }^{24}$ it to Ornithomimus.

Lull recognized the resemblance of these teeth to those of Paleoscincus costatus Leidy. He says:

This tooth [the type] resembles somewhat that of Palaeoscincus costatus Leidy, from the Judith River beds, though the type of Palaeosincus is slightly smaller than that of the present species. The swelling shoulder in Priconodon is more prominent and rounded than in Palaeoscinus, and in the latter the cusps are much sharper and more prominent, though less numerous on one edge of the crown. The median ridge of Priconodon is also lacking.

In his concluding remarks Lull says:

The tooth of Priconodon comes nearest Leidy's Palaeoscincus from the Judith River, to which it could readily be ancestral, as the evolutionary tendency on the part of the Orthopoda is to increase the number and decrease the size of the teeth.

${ }^{22}$ Amer. Journ. Sci., ser. 3, 1888, vol. 25, p. 93, figs. 7-9.

${ }^{23}$ Report Maryland Geol. Survey, Lower Cretaceous, 1911, p. 208.

24 Bull. 110 U. S. National Museum, 1920, p. 142. 
After comparing the type and other teeth of Priconodon with the teeth of Palaeoscincus and Stegosaurus in the National Museum collections, I fully concur in Lull's conclusions as to their close resemblance to those of Palaeoscincus, but do not see that they are any closer to the latter than to Stereocephalus tutus Lambe, ${ }^{25}$ also an Upper Cretaceous form from the Belly River of Alberta, Canada.

In size, method of wear, and general characteristics the teeth of Priconodon certainly indicate closer affinities with the armored dinosaurs of the Upper Cretaceous than with Stegosaurus of the Morrison formation.

Although our classification of the American armored dinosauria is somewhat in confusion at the present time, the discoveries of recent years, much of the material as yet undescribed, shows that the Upper Cretaceous forms belong to families distinct from the Morrison Stegosauridae. Whether the Nodosauridae, Ankylosauridae, or Scelidosauridae all represent valid families I am not prepared to say, but it is to one of these, probably the Nodosauridae, that Priconodon should be assigned rather than the tall plated Stegosauridae as classified by Hay, ${ }^{26}$ Lull, ${ }^{27}$ and others.

\section{Order LORICATA}

\section{Family CROCODYLIDAE.}

\section{GONIOPHOLIS? AFFINIS Lull.}

Plate 110, fig. 1.

This crocodilian was founded on very scanty materials, the selected type being the crown of a single tooth (Cat. No. 8452, U.S.N.M.) (pl. 110, fig. 1), though other teeth and part of a dermal scute were mentioned in the original description. ${ }^{28}$

Lull points out that while the teeth resemble, in size and shape, those of crocodiles from the Morrison formation, yet they differ by "having secondary ridges between the main ridges on the proximal portion of the crown." The sculpturing of the scute is also shown to be coarser than on any of those from the Morrison of the West.

In view of the present state of our knowledge concerning the extinct Crocodilia I do not believe it is possible to definitely determine the genus to which a form based on such meager materials belongs, and until more diagnostic specimens are found it will undoubtedly remain a species of uncertain affinities. At this time it has no apparent value for the correlation of this fauna and should be eliminated from such consideration. Except for showing the presence in the Arundel fauna of an extinct crocodilian these fragmentary specimens have but little significance.

${ }_{25}$ Contributions Canadian Paleontology, vol. 3, pl. 2, 1902, pp. 55-57.

${ }^{26}$ Bull. 179, U. S. Geol. Surv., 1902, p. 496.

n7 Rept. Md. Geol. Surv., 1911, Lower Cret., p. 207.

${ }_{23}$ Idem, pp. 210-211, pl. 20, fig. 7. 


\section{Order TESTUDINATA. \\ Family PLEUROSTERNIDAE.}

GLYPTOPS CAELATUS Hay.

There have been no additional discoveries of turtle remains in the Arundel formation since Dr. O. P. Hay described ${ }^{29}$ Glyptops caelatus in 1908, so that our knowledge of this form rests entirely on the type, a fragmentary specimen, from which little information can be obtained as to its relationships to the other species of the genus. At my request Doctor Hay was kind enough to reexamine the type materials for the present study and reports as follows:

I can not say whether Glyptops caelatus is more or less closely related to the Morrison forms than to those from the Lower Cretaceous. In comparing the Morrison and Arundel faunas I think I would not put $G$. caelatus in the balance.

From the above statement it appears, therefore, on the highest authority, that the Arundel turtle remains can not contribute anything of value to the present discussion of this fauna.

\section{CLASS PISCES.}

At this time the known fish remains of the Arundel fauna consist of a single scale of a Ganoid and a tooth which, in the sculpturing of its flattened grinding surface, slightly resembles those of Ptychodus from the Niobrara formation of the Upper Cretaceous. It probably represents an undescribed form. The specimen (Cat. No. 10294, U.S.N.M.) was found by Mr. C. Englehart in 1894 near Contee, Maryland.

\section{SUMMARY.}

In the preceding review of the several genera and species of fossil vertebrates that comprise the known fauna of the Arundel formation of Maryland, it is apparent that most of them were established on very meager and, in some instances, inadequate materials. The proper treatment of such more or less indeterminate forms has long been one of the difficult problems in modern vertebrate paleontology. In the handling of this fauna in the past, but little discrimination has been made as to the adequate or inadequate nature of the specimens on which the names were based. To regard all members of a fauna as generically and specifically determinable, when from the very character of the type specimens they can only be determined as to order or family, is an erroneous practice.

While in making up faunal lists it is necessary to include such forms, it should always be specified to what extent such questionable genera and species are determinable. The neglect of such a precaution has in the past sadly misled workers in their final conclusions 
where faunal lists have been used to prove the synchronous nature of widely separated formations.

The contention of Marsh, ${ }^{30}$ corroborated by Hatcher, ${ }^{31}$ and the later even more positive assertion of Lull ${ }^{32}$ that the Arundel fauna "correlates the beds wherein they are found absolutely with the Morrison (Como) of the west," is a conclusion which this recent study shows can not be maintained.

Forms that have been founded on single teeth or a single bont, especially in the reptilia, do not permit of an accurate diagnosis of that form, and neither does it permit of a satisfactory comparison with other specimens. Some of these, as the types of Coelurus gracilis, Dryptosaurus? medius, and Dryptosaurus? potens, are certainly determinable as to suborder, possibly family, but are not surely determinable generically, as the genera of carnivorous dinosaurs are now distinguished. The remaining Theropod, Ornithomimus affinis, is certainly distinguishable as to family, possibly as to genus.

While the synonymy of the two genera and three species of the Sauropoda found in the Arundel fauna is somewhat uncertain at this time, the materials are entirely sufficient on which to characterize at least one good genus and two species, and for the purposes of the present discussion this appears entirely adequate.

The Orthopoda is represented by the single genus and species, Priconodon crassus, based on a single tooth. At this time our knowledge of the armored dinosauria is such that we do not know whether the teeth are diagnostic of genera or not. Taking into account the highly specialized character of the teeth in the few known forms, it would appear that perhaps in this group of reptiles, when sufficiently well known, it will be found that the teeth are diverse enough in their characters to at once tell to which particular genus they pertain.

The above review of determined forms shows the evidence for the correlation of the Arundel fauna with the Morrison, rests entirely on the presence of Sauropodous dinosaurs in both formations, and the apparent occurrence of one genus Astrodon (Pleurocoelus) common to both, although a review of the Morrison materials identified as pertaining to Astrodon (Pleurocoelus) by both Marsh and Hatcher is scanty and not altogether reassuring as to the soundness of their identifications. It is my conclusion that, with the exception of Astrodon (Pleurocoelus), there is not another one of the named dinosaurian specimens from the Arundel which at this time can be said to be closely allied to any of the Morrison forms.

On the other hand the presence of an Ornithomimid dinosaur pertaining to the family Ornithomimidae, which has never before been

\footnotetext{
${ }^{30}$ Amer. Journ. Sci., vol. 11, 1896, pp. 435-436.

${ }^{31}$ Annals Carnegie Museum, vol. 2, 1903, pp. 13-14.

${ }^{32}$ Lower Cretaceous, Geol. Survey of Maryland, 1911, p. 178.
} 
known below the Upper Cretaceous (Belly River); an armored dinosaur, Priconodon crassus, which Lull, correctly recognizes as having its closest affinities with Palaeoscincus of the Upper Cretaceous; a carnivorous dinosaur having a caudal vertebra most nearly resembling the Upper Cretaceous Dryptosaurus from New Jersey; and the smaller Theropod Coelurus? gracilis based on a claw of the fore foot, that except for its much smaller size has its exact counterparts in collections from the Belly River formation.

Summing up the evidence, such as it is, we have on the one hand in the Arundel the presence of Sauropodous dinosaurs which have been generally considered as not having survived after the close of the Morrison, and on the other hand one family of known Upper Cretaceous occurrence, and at least three other forms which have their closest resemblances with Upper Cretaceous dinosaurs. Imperfect as it is, the weight of the vertebrate evidence would appear to favor a higher position in the geological scale than has been attributed this fauna in the past.

In this connection it is of interest to find that this conclusion is more in accord with the paleobotanical evidence, as interpreted by Berry, than the previously accepted correlation of the Arundel with the Morrison. Berry, ${ }^{33}$ in comparing the floras of the Arundel and Kootanie of Montana, observes:

The two floras have a great many elements in common, and upon the basis of the floras alone the conclusion would be reached that the base of the Kootanie was approximately the same age or slightly older than the base of the Patuxent (a formation conformably underlying the Arundel). When the faunas are considered it develops that the Morrison fauna, which is considered by many paleontologists to be of Jurassic age, is found conformable beneath the beds containing the Kootanie flora, which is of unquestioned Lower Cretaceous age. Along the Atlantic seaboard this is reversed and the bulk of the flora corresponding to that of the Kootanie underlies beds containing a large representation of the Morrison fauna, and which also has been considered to be Jurassic age by Marsh and others.

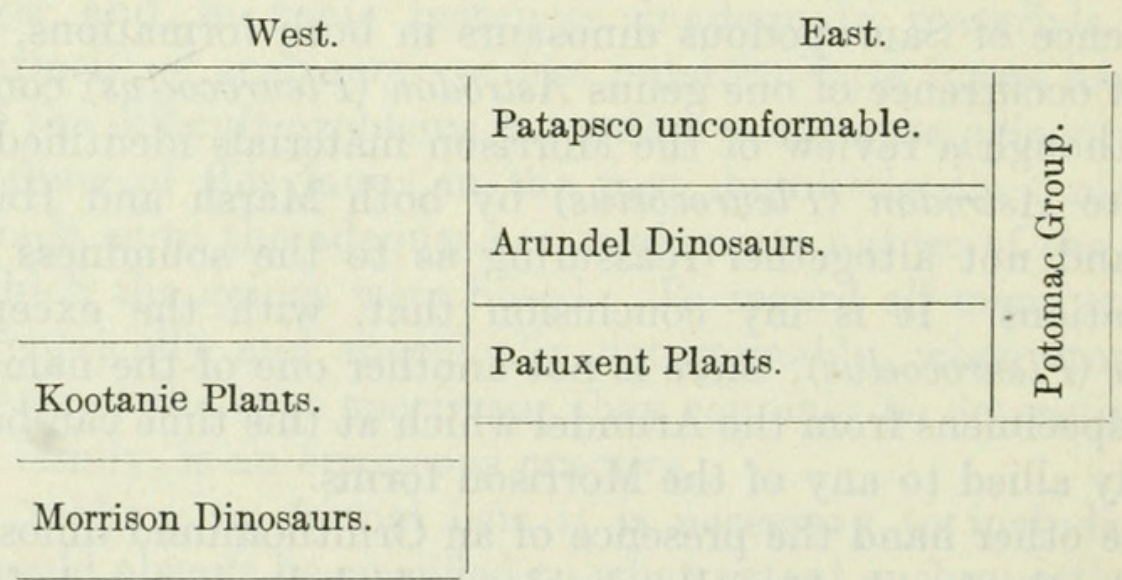

${ }^{33}$ Lower Cretaceous, Maryland Geol. Survey, 1911, pp. 155-156. 
Berry's conclusion, based alone on the evidence of the floras, that the Patuxent and Kootanie formations are of approximately the same age, as graphically shown in the foregoing diagram, is now fully in accord with the vertebrate evidence as indicating a higher position in the Lower Cretaceous for the Arundel formation than has been previously given it. The only difference between these two lines of evidence is that, whereas "the Patuxent-Arundel floras are essentially a unit of early cretaceous age whose affinities all lie with the floras which preceed them," the affinities of the Arundel vertebrate fauna is divided, the Sauropod dinosaurs having close relationships with the preceding fauna and all others apparently having their closest affinities with those faunas which succeeded the Arundel.

\section{EXPLANATION OF PLATES.}

Plate 110.

FIg. 1. Tooth of Goniopholis? affinis Lull. Type. Cat. No. 8452, U.S.N.M. Natural size after Lull. See p. 589.

Fig. 2. Tooth of Dryptosaurus? medius (Marsh). Type. Cat. No. 4972, U.S.N.M. Natural size. Lateral view. See p. 583.

Fig. 3. Tooth of Priconodon crassus Marsh. Type. Cat. No. 2135 U.S.N.M. Natural size. Outer, edge, and inner views. After Marsh. See p. 588.

Frg. 4. Ungual phalanx of the manus of an unidentified dinosaur from the Belly River formation, Upper Cretaceous of the Red Deer River, Alberta, Canada. Cat. No. 5387, Amer. Mus. Nat. Hist. Twice natural size. Lateral view. See p. 586.

Frg. 5. Ungual phalanx of the manus of Coelurus? gracilis Marsh. Type. Cat. No. 4973, U.S.N.M. Twice natural size. Lateral view. With the exception of the difference in size, note the close similarity of figures 4 and 5 . See p. 585 .

\section{Plate 111.}

Fig. 1. Anterior caudal centrum of Antrodemus valens Leidy. From the Morrison formation of Wyoming. Cat. No. 8367, U.S.N.M. About one-half natural size. Viewed from the left side. See p. 584.

Fig. 2. Anterior caudal centrum of Dryptosaurus? potens (Lull) from the Arundel formation of Maryland. Type. Cat. No. 3049, U.S.N.M. About one-half natural size. Viewed from the left side. Compare the straight ventral border of this bone with the anterior caudals of Dryptosaurus aquilunguis, pl. 114, fig. 2. See p. 584 .

\section{Plate 112.}

FIG. 1. Second phalanx digit III, right, of Ornithomimus affinis Gilmore, Cotype. Cat. No. 5703, U.S.N.M. Anterior view. Natural size. See p. 586.

FIg. 2. Second phalanx digit III, right, of an Ornithomimid dinosaur from the Belly River formation, Upper Cretaceous, Alberta, Canada. Cat. No. 5201, Amer. Mus. Nat. Hist. Anterior view. Natural size. See p. 586.

FIg. 3. Proximal phalanx of digit II, left Ornithomimus affinis Gilmore, Cotype. Cat. No. 5453, U.S.N.M. Anterior view. Natural size. See p. 586.

FIg. 4. Proximal phalanx of digit II, left, of an Ornithomimid dinosaur, same as fig. 2. Natural size. See p. 586 . 


\section{Plate 113.}

Fig. 1. Second phalanx digit IV, right, of Ornithomimus affinis Gilmore, Cotype. Cat. No. 8456, U.S.N.M. Anterior view. Natural size. See p. 586.

FIG.2. Second phalanx digit III, right of an Ornithomimid dinosaur from the Belly River formation, Upper Cretaceous, Alberta, Canada. Cat. No. 5201, Amer. Mus. of Natural History. Anterior view. Natural size. See p. 586.

FIG. 3. Distal portion of metatareal III, right of Ornithomimus affinis Gilmore, Lotype. Cat. No. 5684, U.S.N.M. Anterior view. Natural size. See p. 586.

FIG. 4. Distal portion of metatarsal III, left of an Ornithomimid dinosaur from the Belly River formation, Upper Cretaceous of Alberta, Canada. Cat. No. 5201, Amer. Mus. Nat. History. Anterior view. Natural size. See p. 586.

\section{Plate 114.}

FIG. 1. Distal portion of metatarsal II, right, of Onithomimus affinis Gilmore. Cotype. Cat. No. 5704, U.S.N.M. Lateral view. Natural size. See p. 586.

FIG. 2. Anterior caudal vertebrae of Dryptosaurus aquilunguis Cope. Very much reduced. Compare with fig. 2. Plate II. After Cope. See p. 584. 


\section{$2 \mathrm{BHL}$ Biodiversity Heritage Library}

Gilmore, Charles W. 1921. "The fauna of the Arundel formation of Maryland." Proceedings of the United States National Museum 59(2389), 581-594.

https://doi.org/10.5479/si.00963801.59-2389.581.

View This Item Online: https://www.biodiversitylibrary.org/item/32485

DOI: https://doi.org/10.5479/si.00963801.59-2389.581

Permalink: https://www.biodiversitylibrary.org/partpdf/18497.

\section{Holding Institution}

Smithsonian Libraries

\section{Sponsored by}

Smithsonian

\section{Copyright \& Reuse}

Copyright Status: NOT_IN_COPYRIGHT

This document was created from content at the Biodiversity Heritage Library, the world's largest open access digital library for biodiversity literature and archives. Visit BHL at https://www.biodiversitylibrary.org. 